\title{
PENDAYAGUNAAN ZAKAT UNTUK PENANGGULANGAN PANDEMI COVID-19: PERPEKTIF FILSAFAT HUKUM ISLAM
}

\author{
Irfandi \\ IAIN Pekalongan \\ irfandialzasthrowy@gmail.com \\ Nurul Maisyal \\ IAIN Pekalongan \\ nmaisyal@gmail.com
}

\begin{abstract}
The global pandemic Covid-19 that occurred in Indonesia made people experience a difficult situation that requires assistance in terms of support, material and financial. Zakat as a source of social funds in Islam has a strategic role to meet these needs. This study examines the importance of zakat for tackling the Covid19 pandemic. This research is a library research and data collection technique carried out through library studies, using Islamic legal philosophy approach, and results in the conclusion that zakat may be given to Covid-19 affected parties, both for medical teams, corona patients and one of citizens who family has confirmed positive corona, people affected by PHK due to phsycal or social distancing implemented by the government to minimize the transmission of Covid-19, etc.
\end{abstract}

Keywords: distribusing zakat, covid-19, islamic law.

\begin{abstract}
Abstrak
Pandemi global terkait covid-19 yang terjadi di Indonesia menjadikan manusia mengalami situasi kesulitan yang memerlukan bantuan dari sisi dukungan, materi maupun finansial. Zakat sebagai salah satu sumber dana sosial dalam Islam memiliki peran strategis untuk memenuhi kebutuhan tersebut. Penelitian ini mengkaji tentang pentasarufan zakat untuk penanggulangan pandemi Covid-19. Penelitian ini adalah library research dan teknik pengumpulan data dilakukan melalui studi kepustakaan, dengan pendekatan filsafat hukum Islam, dan menghasilkan konklusi bahwa zakat boleh diberikan kepada pihak terdampak Covid-19, baik bagi tim medis, pasien corona maupun warga yang salah satu keluarganya terkonfirmasi positif corona, orang yang terkena PHK akibat phsycal atau social distancing yang diterapkan oleh pemerintah untuk meminimalisir penularan Covid-19, dan lain sebagainya.
\end{abstract}

Kata Kunci: pentasarufan zakat, covid-19, hukum islam. 


\section{Pendahuluan}

Covid-19 telah menjadi pandemi global setelah organisasi kesehatan dunia WHO menetapkannya sebagai pandemi pada 11 Maret 2020. ${ }^{1}$ Virus yang memiliki ciri khas mudah menular ini menimbulkan berbagai dampak buruk bagi semua lini kehidupan umat manusia, termasuk utamanya dalam bidang kesehatan dan ekonomi. Pembatasan Sosial yang diberlakukan pemerintah untuk mengurangi penyebaran virus ini secara langsung berdampak pada pelemahan ekonomi dan penurunan aktivitas usaha. Kondisi ini memerlukan penanganan yang melibatkan seluruh elemen masyarakat dan membutuhkan biaya yang besar. Salah satu sumber dana yang dapat dimanfaatkan untuk mengatasi keadaan ini adalah zakat.

Pemanfaatan zakat secara normatif sudah ditegaskan dalam al-Quran surah at Taubah ayat 60 yang secara eksplisit menentukan bahwa pemanfaatan zakat bersifat khusus dan terbatas untuk delapan golongan. Zakat sebagai salah satu bagian terpenting dari syariat Islam, tidak dapat terhindar dari perkembangan dan perubahan pada pengaturannya. ${ }^{2}$ Perkembangan penafsiran atas delapan golongan penerima zakat, selain karena perubahan zaman, juga dilatarbelakangi keyakinan para ulama dan pengkaji hukum Islam, bahwa Islam adalah agama yang ajarannya senantiasa berkesusaian dengan setiap tempat dan waktu. Juga didasari keyakinan bahwa Islam adalah agama kemanusiaan, dengan pengertian bahwa segala aturan dan hukumnya dibuat untuk kemaslahatan manusia. ${ }^{3}$ Pada aras ini, zakat tidak hanya dipandang dari dimensi ritualta'abbudi saja, melainkan juga perlu dikaji dari perspektif filosofis pensyariatannya (hikmatu tasyri' wa maqşaduhâ), agar sisi kemanusiaan dari ajaran Islam tidak hanya menjadi doktrin saja, tapi dapat mewujud dalam kehidupan nyata.

\footnotetext{
${ }^{1}$ https://www.who.int/publications/en/

${ }^{2}$ Muhammad Firdaus, "Investasi Uang Zakat oleh Lembaga Zakat Menurut Pandangan Islam”, dalam JII, Vol. 1 No, 2016, h. 2

${ }^{3}$ Kemaslahatan manusia secara garis besar terdiri dari menjaga agama, jiwa, akal, harta dan keturunan. Lihat : Ainiah Abdullah, "Maslahah dalam Pelegalan Tas'ir Ibnu Qayyim alJauziyyah", dalam al-Muamalat Jurnal Hukum Ekonomi Syariah IAIN Langsa, Vol IV, No 01. Tahun 2019, h. 71
} 
Urgensi mewujudkan makna kemanusiaan Islam semakin meningkat manakala umat manusia dihadapkan pada situasi kesulitan yang memerlukan bantuan dari sisi materi dan finansial, seperti saat terjadinya pandemi Covid-19 melanda hampir seluruh negara di dunia dan menimbulkan korban dalam jumlah besar. Sampai dengan 29 April 2020, jumlah korban Covid-19 di dunia sejumlah 2.959.929 dengan korban meninggal sejumlah 202.733 orang, ${ }^{4}$ sedang di Indonesia korban Covid-19 mencapai 9511 dengan jumlah korban meninggal $773 .^{5}$

Dalam kondisi yang kesulitan dan ketidakpastian ini, zakat dapat menjadi instrumen sumber pendanaan dalam pencegahan dan penanggulangan Covid-19. Namun, penggunaan zakat untuk hal tersebut tidak bisa dilakukan secara bebas tanpa batas, tapi harus berdasarkan kriteria yang jelas agar tidak keluar dari batasan-batasan yang sudah menjadi mujma' 'alaîh tentang maşârîf zakâh. Tulisan ini akan mengkaji pemanfaatan zakat dalam upaya penanggulangan pandemi Covid-19. Dengan bahasa yang lebih teknis, artikel ini akan menjawab pertanyaan bidang apa saja yang dapat didanai dari zakat pada masa pandemi Covid-19.

\section{Survey Literatur}

Salah satu topik yang menjadi medan pembahasan para peneliti dan pengkaji hukum Islam kaitannya dengan responsibilitas dan fleksibilitas hukum Islam adalah zakat. Menurut Jamal Abdul Aziz, ${ }^{6}$ kajian tentang pengembangan zakat berkisar seputar pengembangan objek zakat (al-amwâl zakawiyyah) dan pemanfaatannya (maşârîf zakâh). Ada sejumlah tulisan yang mengkaji tentang pemanfaatan zakat dengan titik tumpu perluasan makna aşnâf.

Irfan Syauqi Beik dalam tulisannya "Fiqh of Asnaf in The Distribution of Zakat: Case Study in The National Board of Zakat of Indonesia (Baznas)",

${ }^{4}$ https://covid19.who.int/. Diakses pada 29 April 2020 pukul 07.26.

${ }^{5}$ https://kawalcovid19.blob.core.windows.net/viz/statistik_harian.html, Diakses pada 29 April 2020 pukul 07.26.

${ }^{6} J a m a l$ Abdul Aziz, "Dekonstruksi Paradigmatik PengembanganZakat: Analisis Kritis PemikiranYusuf al-Qaradawi”, dalam Ijtihad: Jurnal Wacana Hukum Islam dan Kemanusiaan, Vol. 12 No. 2 (2017), h. 192 
mendedahkan kebijakan standarisasi aşnâf yang dilakukan oleh Baznas yang dituangkan dalam 11 pasal dalam Peraturan Baznas. Salah satunya korban bencana. Lokus penelitian adalah peraturan baznas secara umum, belum mengerucut pada masa pandemi. ${ }^{7}$

Dalam lingkup yang lebih sempit, Muhammad Ammar Harith Adris dan Mohd Anuar Ramli menulis tentang perluasan makna ibnu sabîl dan riqâb dikaitkan dengan fenomena gelandangan di Malaysia. Ia menyimpulkan bahwa gelandangan dapat diberi bagian zakat dengan memasukkannya sebagai salah satu kategori ibnu sabîl dan riqâb. ${ }^{8}$ Tulisan ini kendatipun telah mengkaji perluasan makna aşnâfibnu sabîl dan riqâb, namun tidak secara langsung mengaitkannya dengan situasi pandemi, sehingga belum menjawab pertanyaan penelitian penulis.

Senada dengan keduanya, Maman Abdul Basith juga telah meneliti pergeseran konsep sabilillah sebagai mustahik zakat mal antara fikih klasik dan pandangan kontemporer. Tulisan ini juga berbeda ruang lingkupnya dengan penelitian penulis. ${ }^{9}$

Andi Suryadi juga menulis perkembangan definisi mustahiq zakat dan menyimpulkan, dari delapan aşnâf, sabîlillah yang paling banyak mengalami perluasan makna, dari jihad fisik menjadi segala macam kebaikan. Faktor yang menyebabkan pergeseran dan perluasan makna adalah mendesaknya kebutuhan dan pentingnya merealisasikan kemaslahatan umat. ${ }^{10}$

Siti Fariza dkk. ${ }^{11}$ dalam tulisannya menyoroti perlunya penerapan kaidah ad-darūrah tuqaddaru biqadarihâdalam pendistribusian zakat untuk korban

${ }^{7}$ Irfan Syauqi Beik dalam tulisannya "Fiqh of Asnaf in The Distribution of Zakat : Case Study in The National Board of Zakat of Indonesia (Baznas)", dalam al-Infaq: Jurnal Ekonomi Islam, Vol. 6, No 2, September 2015, h. 201-217

${ }^{8}$ Muhammad Ammar Harith Adris dan Mohd Anuar Ramli , "Golongan Gelandangan di Malaysia: antara Perluasan Tafsiran Asnaf Ibnu Al-Sabil dan Al-Riqab", dalam Najahudin Lateh, Isu-Isu Kontemporer dalam Zakat, Wakaf dan Filantropi Islam (Selangor Darul Ihsan: Akademi Pengajian Islam Kontemporari, 2017), h. 121-132

${ }^{9}$ Maman Abdul Basith, "Pergeseran Konsep Sabilillah sebagai Mustahik Zakat Mal dari Fiqh Klasik ke Fiqh Kontemporer", Skripsi pada Jurusan Hukum Bisnis Syariah UIN Malang, 2017

${ }^{10}$ Andi Suryadi, "Mustahiq dan Harta yang Wajib Dizakati Menurut Kajian Para Ulama", dalam Jurnal Tazkiya, Vol. 9, No 1 (Janua ri-Juni) 2019

${ }^{11}$ Siti fariza dkk.,"Aplikasi Kaedah Fiqh Al-Darurah Tuqaddar Biqadariha dalam Agihan Zakat untuk Mangsa Banjir” dalam Jurnal Infad, Vol. 8 Tahun 2018 
bencana. Agar penggunaan zakat tidak sesuka hati dan senantiasa berada dalam batasan yang sudah digariskan syariat. Tulisan ini menjadi landasan teori penelitian penulis tentang perlunya batasan pendayagunaan zakat untuk penanggulangan pandemi Covid-19.

Atep Hendang Waluya juga menulis tentang makna fì sabîlillâh, di mana ia menyimpulkan ada tiga kelompok yang memaknai fî sabîlillâh secara beragam, pendapat sempit, pendapat luas dan pendapat moderat. ${ }^{12}$ Penelitian penulis merupakan penelitian lanjutan yang mencoba mengimplementasikan hasil dari upaya yang sudah dilakukan dilakukan oleh Atep ke ranah teknis, khususnya dalam penanggulangan Covid-19.

Mohd Rilizam Rosli, dkk., ${ }^{13}$ juga telah mengkaji implementasi pendistribusian zakat untuk riqâb, namun tidak secara khusus mengaitkannya dengan situasi pandemi, sehingga menyisakan ruang kosong kajian yang penulis jadikan alasan untuk penelitian penulis.

Meskipun sudah cukup banyak tulisan yang mengeksplorasi reinterpretasi aşnâf penerima zakat, namun belum ada tulisan yang secara khusus mengkaji pemanfaatan zakat untuk penanggulangan pandemi, khususnya pandemi Covid-19 yang sedang melanda umat manusia.

\section{Metode Penelitian}

Jenis penelitian ini adalah library research dan teknik pengumpulan data dilakukan melalui studi kepustakaan. Dalam hal ini, sumber yang digunakan adalah sumber data sekunder yang mencakup bahan hukum primer, bahan hukum sekunder dan bahan hukum tersier.Adapun analisis data melalui pendekatan ushul fikih dan filsafat hukum Islam.

\footnotetext{
${ }^{12}$ Atep Hendang Waluya, “Analisis Makna fî̀ sabîlillâh dalam Q.S. Taubah (9): 60 dan Implementasinya dalam Perekonomian”, dalam Jurnal Rausyan Fikr, Vol. 13 No. 1 2017, hal. 1407-1418

${ }^{13}$ Mohd Rilizam Rosli, dkk., "Asnaf Zakat Distribution Mechanism in Today’s World”, dalam International Journal of Academic Research in Business \& Social Science, Vol. 8 No 4, April 2018, h. 1092-1102
} 


\section{Pembahasan}

\section{Zakat dan Filsafat Hukumnya}

Zakat secara bahasa bermakna النمه (bertumbuh), الزيادة (bertambah) (suci) dan المدح (terpuji). ${ }^{14}$ Makna etimologis dari zakat ini menyiratkan makna terminologisnya karena kewajiban zakat, tertentu atas harta yang bertumbuh atau produktif, juga menyiratkan makna filosofisnya, bahwa hikmah dari membayar zakat adalah membuat harta menjadi bertambah, membersihkan hati dari sifat kikir serta membuat orang yang membayarnya mendapatkan predikat terpuji.

\section{Maşârîf Zakât}

Zakat sebagai rukun Islam memiliki perbedaan dengan bentuk dana sosial yang lain seperti infaq, sedekah, hibah dan wakaf. Perbedaan tersebut dilihat dari sisi penerimanya, di mana zakat harus diberikan kepada delapan golongan yang sudah ditentukan oleh Allah secara tegas dan rigid, yaitu fakir, miskin, amil, muallaf, riqâb, gharîm, sabîlillâh dan ibnu sabîl.

1. Fakir. Menurut Asy-Syafi'iyah dan Al-Hanabilah, fakir adalah 'orang yang tidak memiliki harta atau pekerjaan yang dapat memenuhi kebutuhan dasarnya'. ${ }^{15}$ Misalnya orang yang membutuhkan sepuluh dirham, namun hanya menemukan tiga dirham. Sementara menurut Hanafiyyah, fakir adalah orang yang harta produktifnya belum mencapai batas nişâb, atau hartanya sudah mencapai nişâb, namun tidak produktif. ${ }^{16}$ Sedangkan Ulama Malikiyah memaknai fakir dengan "orang yang memiliki harta, namun belum mencukupi untuk memenuhi kebutuhan makanan pokoknya selama setahun"17

2. Miskin. Menurut Ulama Syafi'iyyah, miskin adalah orang yang memiliki harta atau penghasilan tapi belum cukup untuk memenuhi kebutuhan yang layak,

\footnotetext{
${ }^{14}$ Wahbah az-Zuhaili, al-Fiqh al-Islami wa Adillatuh, (Damaskus: Dar el-Fikr, 1985), Juz II, h. $729-730$

${ }^{15}$ Wahbah az-Zuhaili, al-Fiqh al-Islami... 869

${ }^{16}$ Ad-Dasuqi, Hasyiyatu Ad-Dasuqi (Beirut : Dar al-Fikr, th.) jilid 1 halaman 492

${ }^{17}$ Dari definisi-definisi tersebut, nampak jelas bahwa definisi Syafi'iyyah dan Hanabilah lebih ketat dibanding definisi dari Ulama Hanafiyyah dan Malikiyyah. Ulama empat madzhab sepakat adanya syarat bagi fakir untuk menerima bagian zakat, yaitu: 1) muslim, 2) bukan keluarga Nabi, 3) merdeka dan 4) tidak di bawah tanggungan kerabat. Lihat:Ahmad Sarwat, Seri Fiqih Kehidupan : Zakat (Jakarta : DU Publishing, 2011, hal. 256.
} 
seperti orang yang membutuhkan 10 dirham tapi hanya mendapatkan 8 dirham. Dengan kata lain, dia bisa memenuhi kebutuhan asasinya, tapi di bawah standar kelayakan umum. Menurut Hanabilah, batasan miskin ialah jika kadar kebutuhan yang bisa tercukupi di atas $50 \%$. Sementara menurut Malikiyyah dan Hanafiyyah, miskin adalah orang yang tidak memiliki harta atau penghasilan sama sekali. Definisi miskin menurut Hanafiyyah dan Malikiyyah ini sama dengan definisi fakir menurut Syafi'iyyah dan Hanabilah. Syarat untuk menerima bagian zakat bagi si miskin ialah beragama Islam, bukan keluarga nabi dan tidak di bawah tanggungan orang yang menjadi kepala keluarganya. ${ }^{18}$

3. Amil. Amil zakat adalah orang yang secara resmi mendapatkan mandat dari untuk mengumpulkan zakat dari para pemilik harta, dan yang mendistribusikannya kepada pihak yang berhak menerimanya. Syarat untuk menjadi amil adalah Islam, Akil-Baligh, memiliki sifat al- 'adâlah ${ }^{19}$ (integritas) serta faqâhah atau pemahaman terhadap fikih zakat. Bagian zakat untuk amil merupakan upah kerja baginya dalam mengurus zakat, sehingga tidak ada persyaratan miskin baginya untuk menerima bagian zakat. ${ }^{20}$

4. Mua'allaf. Muallaf terdiri dari orang muslim dan non muslim. Muallaf dari non muslim menurut Wahbah az-Zuhaili ada empat kelompok :

a. Orang yang sudah masuk Islam, namun imannya masih lemah

b. Orang yang masuk Islam dan ia memiliki pengaruh di mata kaum atau komunitasnya, meskipun keimanannya sudah kuat

c. Orang yang menjaga benteng kaum muslimin di daerah yang berbatasan dengan kawasan orang kafir

d. Orang yang menjadi relawan zakat di kawasan terpencil yang sulit dijangkau oleh amil zakat. ${ }^{21}$

\footnotetext{
${ }^{18}$ Ahmad Sarwat Seri Fiqih Kehidupan : Zakat (Jakarta : DU Publishing, 2011, hal. 256

${ }^{19}$ 'adalah dalam literatur klasik ialah orang yang tidak melakukan dosa besar dan tidak melanggengkan dosa kecil.

${ }^{20}$ Wahbah az-Zuhaili, al-Fiqh al-Islami... 870

${ }^{21}$ Wahbah az-Zuhaili, al-Fiqh al-Islami... h. 872
} 
Di luar keempat golongan tersebut, ada perbedaan juga pendapat mengenai apakah non muslim dapat diberi bagian zakat? Menurut Hanabilah dan Malikiyyah, mereka dapat diberi zakat sebagai bentuk targhîban fil Islâm (menarik simpati terhadap Islam), atas dasar riwayat sahih yang menyatakan bahwa Rasulullah pernah memberi kepada Abu Sufyan bin Harb, Sofwan bin Umayyah dan 'Uyainah bin Hisn, Aqra' bin Habis dan Abbas bin Mirdas masing-masing seratus ekor unta. ${ }^{22}$ Sedangkan menurut Syafi'iyyah dan Hanafiyyah, orang non muslim tidak diberi zakat dengan alasan apapun. Peristiwa Rasulullah pernah memberi mereka bagian dari zakat bersifat temporer, yaitu saat Islam masih lemah, kaum muslim masih minoritas dan kaum kafir mayoritas. ${ }^{23}$

5. Riqâb. Bagian zakat untuk riqâb terdiri dari tiga bentuk :

a. Diberikan kepada budak mukatab, yakni budak yang sedang mengurus kemerdekaan dirinya dengan cara membayar cicilan pada tuannya.

b. Ulama Hanabilan dan Malikiyyah bependapat bagian zakat bisa digunakan untuk membebaskan budak secara langsung dengan membelinya dari tuannya dan kemudian memerdekakannya

c. Hanabilah berpendapat bahwa bagian zakat bisa digunakan untuk menebus orang muslim yang menjadi tawanan perang. ${ }^{24}$

6. Ghârimîn. Menurut Ulama Syafi'iyyah dan Hanabilah, Ghârim adalah orang yang memiliki hutang, baik untuk kepentingan dirinya maupun untuk kepentingan orang lain. Sedangkan Ghârim menurut Hanafiyyah adalah orang yang memiliki hutang yang sisa hartanya kalau untuk membayar hutang, tidak lebih dari satu nişâb. Sementara Ulama Malikiyyah memaknai ghârim sebagai orang yang memiliki hutang bukan untuk maksiat atau aktivitas pemborosan. ${ }^{25}$ Syarat gharim agar dapat menerima zakat menurut Ulama Syafiiyyah dan Hanabilah, ialah tidak kaya. Jika ia kaya, maka ia hanya berhak menerima

\footnotetext{
${ }^{22}$ Asy-Syaukani, Nailul Author, (Tanpa Kota: Muassasah ar-Risalah, 1420), h. 166

${ }^{23}$ Ahmad Sarwat, Seri Fiqih... hal. 871

${ }^{24}$ Ibid.

${ }^{25}$ Wahbah az-Zuhaili, al-Fiqh al-Islami... h. 873-874
} 
bagian zakat jika hutang yang ia tanggung untuk kepentingan orang lain. ${ }^{26}$ Misalnya hutang untuk mendamaikan dua orang yang berselisih masalah keuangan. Ulama Malikiyyah mensyaratkan hutang tidak digunakan untuk kemaksiatan. Namun jika seseorang telah bertaubat dan memiliki tanggungan hutang saat ia masih menjadi ahli maksiat, maka ia juga berhak diberi zakat

7. Sabilillah. Dalam fikih klasik, sabilillah ialah relawan perang dengan motif membela agama, yang tidak digaji oleh negara. Namun demikian, definisi tersebut menjadi kurang relevan jika dikaitkan dengan realitas masa kini, ketika definisi jihad sudah mengalami pergeseran dan perluasan dari perang fisik menjadi beragam cara menegakkan kalimat Allah. Oleh karena itu, muncul tiga pandangan dalam memaknai sabilillah:

a. Pandangan mudhayyiqîn atau kelompok yang memaknai sabilillah dengan pengertian sempit. Jumhur ulama, termasuk ulama empat madzhab termasuk yang cenderung kepada pendapat ini. Mereka mengatakan bahwa yang termasuk fi sabilillah adalah tentara yang terlibat pertempuran fisik melawan musuh-musuh Allah dalam rangka menegakkan agama Islam. Kesepakatan keempat mazhab tentang fi sabilillah, jihad secara pasti termasuk dalam ruang lingkup fi sabilillah. ${ }^{27}$

b. Pandangan muwassi'în yaitu pandangan kelompok yang mendefinisikan sabilillah dengan pengertian luas. Menurut kelompok ini, ruang lingkup fi sabilillah bukan hanya dalam pertempuran fisik, akan tetapi meluas ke segala lini kebaikan (anwâ'i wujuh al-khairât). Di antara ulama yang berpendapat seperti ini ialah Imam Qaffal, Mazhab Ja'fari, Mazhab Zaidi, Ar Razi, Syeikh Syaltut, Syeikh Muhammad Rasyid Ridha, Syaikh Mustafa Az-Zaeqa dan para ulama kontemporer lainnya.

c. Pandangan pertengahan. Yusuf al-Qaradhawi adalah ulama kontemporer yang memelopori pendapat ini. Menurutnya, tidak tepatmemaknai fi sabilillah menjadi terlalu umum. Karena dengan demikian, maka

${ }^{27}$ Atep Hendang Waluya, “Analisis Makna fi Sabilillah dalam Q.S. Taubah (9): 60 dan Implementasinya dalam Perekonomian", dalam Jurnal Rausyan Fikr, Vol. 13 No. 1 2017, hal. $1407-1418$ 
pentasarufan zakat menjadi luas tanpa batas, dan golongan penerimanya menjadi sangat beragam, sehingga pengkhususan delapan golongan yang digariskan Allah menjadi tidak ada artinya. Sebaliknya, membatasi fi sabilillah pada perang fisik semata juga tidak relevan karena bertentangan dengan realitas kekinian yang semakin berkembang. Sebagai alternatif ia mengambil jalan tengah, bahwa fi sabilillah adalah segala bentuk "peperangan" untuk menegakkan kalimah Allah, termasuk menggunakan akal dan hati dalam membela dan mempertahankan aqidah Islam. Ia mencontohkan fi sabilillah dengan membangun fasilitas dakwah di kawasan di mana Islam menjadi minoritas, mengenalkan keindahan ajaran Islam kepada umat lain, menerbitkan tulisan tentang Islam untuk menjawab serangan terhadap Islam, serta mendirikan pusat-pusat pendidikan yang mengajarkan ajaran-ajaran tauhid. ${ }^{28}$

8. Ibnu Sabil. Ibnu Sabil ialah orang yang kehabisan harta dalam perjalanan, sehingga tidak mampu untuk kembali ke rumahnya. Atau dengan bahasa lain, orang yang berada bukan di kampung halamannya dan kehabisan bekal untuk memenuhi kebutuhan dasar serta perjalanan untuk kembali ke kampung halamannya. Syarat Ibnu sabil untuk menerima zakat hampir sama dengan syarat golongan lain, yakni muslim, bukan ahlul bait, perjalannya bukan perjalanan untuk masiat dan tidak memiliki harta di tangannya. Ulama berbeda pendapat mengenai kasus jika orang yang kehabisan bekal itu termasuk orang yang kaya di kampung halamannya. Apakah tetap diberi dari harta zakat, ataukah seharusnya dia berhutang saja? Ulama Malikiyyah dan Hanafiyyah berpendapat ia tidak diberi zakat, dan harus berhutang untuk mencukupi kebutuhan dasar dan kembali ke kampung halamannya. Sedang ulama Syafi'iyyah dan Hanabilahb berpandangan sebaliknya, bahwa ia tetap diberi zakat, kendatipun di kampung sebenarnya ia orang yang mampu. Bagaimanapun juga, ia dalam kondisi sangat membutuhkan bantuan. ${ }^{29}$

\footnotetext{
${ }^{28}$ Ibid.

${ }^{29}$ Fakhruddin Arrazi bin Yusof, "Status Hukum Pemberian Zakat bagi Ibnu Sabil yang Kaya di Tempat Asal (studi komparatif antara Imam Kamal Al-Din Muhammad 861 M dan Imam
} 


\section{Tujuan Pensyariatan Zakat}

Imam ath-Thabari dalam kitab tafsirnya Jâmi' al-Bayân menjelaskan bahwa zakat memiliki dua tujuan pokok: a. Pemenuhan kebutuhan kaum muslim معونة الإسلام (dan b. Menolong dan menguatkan agama Islam (سد خلة المسلمين) (وتقويته ${ }^{30}$

Rasyidal-Syamghuli dalam artikelnya "Maqâşid al-Syarî'ah li Nidzâm alZakâh" mengelaborasi secara lebih rinci tentang tujuan zakat. Menurutnya tujuan zakat dapat dilihat dari lima dimensi : dimensi ta'abbudi, dimensi tarbawi, dimensi ijtima'i, dimensi ekonomi dan dimensi dakwah

1. Dimensi ta'abbudi. Pada aspek ini, zakat memiliki empat tujuan :

a. Sebagai bentuk deklarasi atau pengakuan terhadap keislaman.

b. Sebagai bentuk ketundukan pada titah Allah.

c. Sebagai bentuk wujud rasa syukur orang muslim kepada Tuhan.

d. Sebagai bukti atau indikator atau bukti akan kebenaran iman di hati seorang mukmin

2. Dimensi Tarbawiyyah. Pada aspek ini, pensyariatan zakat memiliki beberapa tujuan

a. Tujuan membersihkan harta dari unsur-unsur yang mengurangi keberkahan harta, seperti unsur perkara haram yang tidak disengaja dan unsur syubhat.

b. Tujuan membersihkan dari penyakit hati berupa rakus dan serakah.

3. Dimensi Sosial. ${ }^{31}$

Nawawi 1277 M)", Skripsi pada Jurusan Perbandingan Madzhab dan Hukum UIN Suska Riau, 2019

${ }^{30}$ Muhammad bin Jarir at-Thabari, Jami’ al-Bayan (Tanpa Kota: Muassasah ar-Risalah, $1420 \mathrm{H})$, h. 316

${ }^{31} \mathrm{M}$ Fuad Nasar menuturkan bahwa sumber pendanaan jaminan sosial dalam Islam terdiri dari Zakat, infaq, wakaf, wasiat, ghanimah (rampasan perang), rikaz (harta karun), nadzar, kifarat, kurban, zakat fitrah, fidyah puasa dan kas perbendaharaan negara (baitul mal) dalam M Fuad Nasar, 2018, Capita Selecta Zakat : Esei-Esei Zakat, Aksi Kolektif Melawan Kemiskinan (Yogyakarta: Gre Publishing), hal. 61. Dalam literatur fikih banyak dijumpai pembahasan seputar 'apakah ada kewajiban lain dalam harta seorang muslim selain zakat'? Sebagian ulama berpendapat yang wajib hanyalah zakat. Sedangkan sebagian yang lain berpandangan sebaliknya. Ibnu Hazm berkata : "Diwajibkan bagi orang kaya untuk ikut menanggung kebutuhan kelompok fakir. Bagi 
4. Dimensi Ekonomi. Pada aspek ini, zakat memiliki beberapa tujuan :

a. Sebagai upaya pengentasan kemiskinan

b. Sebagai upaya berputarnya uang dan berjalannya roda ekonomi; serta

c. Sebagai instrumen investasi, yakni manakala harta zakat diberikan tidak dalam bentuk tunai, tapi dalam bentuk kegiatan produktif.

5. Dimensi Dakwah. Aspek dakwah dari zakat dapat dilihat dari dimasukkannya muallaf dalam kelompok mustahiq zakat. ${ }^{32}$

\section{Konsep Pentasarufan Zakat di Indonesia}

Pentasarufan dalam Peraturan Badan Amil Zakat Nasional Republik Indonesia Nomor 3 Tahun 2018 dapat berbentukpendistribusian dan pendayagunaan zakat. Dalam pasal 4 dikatakan bahwa pendistribusian zakat dilakukan terhadap bidang:

a. Pendidikan. Dapat diberikan dalam bentuk biaya pendidikan baik langsung maupun tidak langsung.

b. Kesehatan (dapat diberikan dalam bentuk pengobatan kuratif.)

c. Kemanusiaan. Dapat diberikan dalam bentuk penanganan korban bencana alam, korban kecelakaan, korban penganiayaan, dan korban tragedi kemanusiaan lainnya.

d. Dakwah dan advokasi.Dapat diberikan dalam bentuk bantuan kepada penceramah, pembangunan rumah ibadah umat Islam, dan bantuan lain yang membantu kegiatan dakwah dan advokasi.

Sedangkan pendayagunaan zakat dapat dilakukan dalam bidang:

Penguasa boleh memaksa mereka untuk melakukan itu jika harta zakat belum mencukupi kebutuhan sehari-hari mereka" Abu Bakr Ibn Al Arabi berkata : "Tidak ada kewajiban lain terkait harta selain zakat. Meskipun demikian, jika zakat sudah ditunaikan tapi belum mencukupi kebutuhan pokok kaum fakir, maka bagi orang-orang kaya wajib untuk mengeluarkan harta mereka untuk memenuhi kebutuhan kaum fakir tersebut. Senada dengan itu, Imam Malik memberikan fatwa kewajiban untuk menebus tawanan kaum muslim, walaupun untuk itu harus menghabiskan seluruh harta.

${ }^{32}$ Rasyid al-Syamghuli, "Maqasid al-Syariah Li Nidzam al-Zakah", dalam Jurnal Majallah Jamiah al-Quds al-Maftuhah li al-Buhuts al-Insaniyyah wa al-Ijtima 'iyyah, Vol. 46, 2018 
a. Ekonomi. Dapat diberikan dalam bentuk bantuan yang bertujuan untuk mengentaskan kemiskinan, meningkatkan kapasitas produktif, kewirausahaan, meningkatkan kesejahterahaan mustahiq, pemberdayaan komunitas mustahiq berbasis kewilayahan dan potensi ekonomi lokal.

b. Pendidikan. Dapat diberikan dalam bentuk bantuan peningkatan kompetensi keterampilan hidup, kepemimpinan, kewirausahaan, serta pembangunan sarana dan prasarana pendidikan.

c. Kesehatan. Dapat diberikan dalam bentuk bantuan kesehatan promotif dan preventif, serta pembangunan sarana dan prasarana kesehatan.

Pasal 27 Ayat (1) dan (2) Undang-Undang Nomor 23 Tahun 2011 tentang pengelolaan zakat menyatakan bahwa zakat dapat diberdayakan untuk masyarakat ekonomi lemah.Kategori masyarakat dengan ekonomi lemah ini disebut dengan mustahiq zakat. Pemberdayaan dalam konteks pendayagunaan zakat sebagaiamana dari pasal di atas bertujuan mengangkat derajat kelompok lemah menjadi kelompok yang mendiri secara ekonomi.

Para ahli hukum Islam kontemporer berijtihad bahwa dana zakat sebaiknya dapat digunakan untuk kepentingan yang memiliki nilai manfaat besar bagi kesejahteraan umat. Efektivitas pemberdayaan zakat untuk usaha produktif, terkait erat dengan posisi dan peran amil. Sesuai dengan perkembangan kontemporer, peran amil zakat bukan hanya sebatas pengumpulan, pengelolaan, dan pendistribusian zakat untuk aspek konsumtif, melainkan juga telah merambah kepada upaya pemberdayaan zakat untuk usaha-usaha produktif dalam peningkatan kesejahteraan umat. $^{33}$

Zakat yang diserahterimakan kepadamustahiq zakat dapat berupa in cash (uang tunai) atau in kind dalam bentuk program. Al-Qur'an tidak menjelaskan secara terperinci dan detail tentang teknis pendistribusian dan pendayagunaan zakat. Namun demikian, paparan Al-Qur'an tentang delapan kelompok zakat yang meliputi fakir, miskin, 'āmil zakāt, muallaf, riqāb,

${ }^{33}$ Yeni Triana, dkk, Kontekstualisasi Pendayagunaan Zakat di Badan Amil Zakat Nasional (Baznas) Kota Pekanbaru Berdasarkan Undang-Undang Nomor 23 Tahun 2011 Tentang Pengelolaan Zakat, dalam Jurnal Hukum Novelty Vol. 9 No. 1 Agustus 2018, hlm. 72. 
ghārim, fì sabīlillah dan ibnu al-sabīl sebagai prinsip pendayagunaan zakat yang harus dipedomani dan diimplementasikan oleh setiap pengelola dana zakat.

Pendayagunaan zakat dapat berpedoman pada penjelasan al-Quran yang dikontekstualisasikan saat ini: 1) Allah tidak menetapkan perbandingan yang tetap antara bagian masing-masing 8 (delapan) pokok alokasi (aşnâf); 2) Allah tidak menetapkan delapan asnaf harus diberi semuanya, Allah hanya menetapkan zakat dibagikan kepada delapan aşnâf, tidak boleh keluar daripada delapan asnāf; dan 3) Allah tidak menetapkan zakat harus dibagikan dengan segera setelah masa pungutan zakat. Selain itu, tidak ada ketentuan bahwa semua hasil pungutan zakat (baik sedikit maupun banyak) harus dibagikan semuanya. ${ }^{34}$

\section{Anatomi Pandemi Covid-19}

Virus Corona atau yang dikenal dengan Covid-19 berawal pada Desember 2019, ketika WHO China Country Office melaporkan kasus pneumonia yang tidak diketahui etiologinya di Kota Wuhan, Provinsi Hubei, Cina. Pada tanggal 7 Januari 2020, Cina mengidentifikasi pneumonia yang tidak diketahui etiologinya tersebut sebagai jenis baru coronavirus (coronavirus disease, COVID-19).Pada tanggal 30 Januari 2020, WHO telah menetapkan sebagai Public Health Emergency of International Concern (PHEIC). Penambahan jumlah kasus COVID-19 berlangsung cukup cepat dan sudah terjadi penyebaran ke luar wilayah Wuhan dan negara lain.

Ada tiga jalur utama yang mungkin ditempuh penyakit ini.Pertama, penyakit mungkin berbentuk ringan yang menyerupai penyakit pernapasan atas umum lainnya.Kedua, mengarah ke pneumonia, yaitu infeksi pada sistem pernapasan bawah.Ketiga, yang paling parah, adalah perkembangan cepat ke sindrom gangguan pernapasan akut (acute respiratory distress syndrome atau ARDS). ${ }^{35}$

${ }^{34}$ Yusuf Al-Qaradawi, Fiqh Al-Zakah ()

${ }^{35}$ Heymann, David L; Shindo, Nahoko (2020). "COVID-19: what is next for public health?". The Lancet. Elsevier BV. 395 (10224): 542-545.Lihat: Wikipedia, Penyakit Koronavirus, https://id.wikipedia.org/wiki/Penyakit_koronavirus_2019, diakses pada 1 April 2020 . 
Tanda-tanda dan gejala klinis yang dilaporkan sebagian besar adalah demam, dengan beberapa kasus mengalami kesulitan bernapas, dan hasil rontgen menunjukkan infiltrat pneumonia luas di kedua paru. Menurut hasil penyelidikan epidemiologi awal, sebagian besar Pedoman Kesiapsiagaan Menghadapi Coronavirus Disease (COVID-19) 12 kasus di Wuhan memiliki riwayat bekerja, menangani, atau pengunjung yang sering berkunjung ke Pasar Grosir Makanan Laut Huanan. Sampai saat ini, penyebab penularan masih belum diketahui secara pasti. $^{36}$

\section{Cara Penularan}

Coronavirus (CoV) adalah keluarga besar virus yang menyebabkan penyakit mulai dari gejala ringan sampai berat.Ada setidaknya dua jenis coronavirus yang diketahui menyebabkan penyakit yang dapat menimbulkan gejala berat seperti Middle East Respiratory Syndrome (MERS) dan Severe Acute Respiratory Syndrome (SARS).Coronavirus Disease (COVID-19) adalah virus jenis baru yang belum pernah diidentifikasi sebelumnya pada manusia.Virus corona adalah zoonosis (ditularkan antara hewan dan manusia).Penelitian menyebutkan bahwa SARS ditransmisikan dari kucing luwak (civet cats) ke manusia dan MERS dari unta ke manusia.Beberapa coronavirus yang dikenal beredar pada hewan, namun belum terbukti menginfeksi manusia.

WHO melaporkan bahwa penularan dari manusia ke manusia terbatas (pada kontak erat dan petugas kesehatan) telah dikonfirmasi di China maupun negara lain. ${ }^{37}$ Berdasarkan kejadian MERS dan SARS sebelumnya, penularan manusia ke manusia terjadi melalui percikan (droplet), kontak dan benda yang

\footnotetext{
${ }^{36}$ Merry Dame Cristy Pane, Virus Corona, https://www.alodokter.com/virus-corona , diakses pada 20 Maret 2020.

${ }^{37}$ Rekomendasi standar untuk mencegah penyebaran infeksi adalah melalui CTPS (Cuci Tangan Pakai Sabun) secara teratur, menerapkan etika batuk dan bersin, menghindari kontak secara langsung dengan ternak dan hewan liar serta menghindari kontak dekat dengan siapa pun yang menunjukkan gejala penyakit pernapasan seperti batuk dan bersin. Selain itu, menerapkan Pencegahan dan Pengendalian Infeksi (PPI) saat berada di fasilitas kesehatan terutama unit gawat darurat.Lihat pada: Fathiyah Isbaniah, dkk., Pedoman Kesiapsiagaan Menghadapi Coronavirus Disease (COVID-19), Kementerian Kesehatan RI Direktorat Jenderal Pencegahan dan Pengendalian Penyakit: Jakarta Selatan, 2020, hlm. 11.
} 
terkontaminasi, maka penularan COVID-19 diperkirakan sama.Seseorang dapat tertular COVID-19 melalui berbagai cara, yaitu:

1) Tidak sengaja menghirup percikan ludah dari bersin atau batuk penderita COVID-19.

2) Memegang mulut atau hidung tanpa mencuci tangan terlebih dulu setelah menyentuh benda yang terkena cipratan air liur penderita COVID-19.

3) Kontak jarak dekat dengan penderita COVID-19, misalnya bersentuhan atau berjabat tangan.

Guna memastikan diagnosis COVID-19, dokter akan melakukan pemeriksaan lanjutan seperti uji sampel darah, tes usap tenggorokan untuk meneliti sampel dahak (tes PCR), rontgen dada untuk mendeteksi infiltrat atau cairan di paru-paru. ${ }^{38}$

\section{Masa Inkubasi Virus Corona}

Virus corona jenis baru penyebab Covid-19 masih terus diteliti.Masih banyak yang belum diketahui dengan pasti mengenai virus SARS-CoV2, varian baru dari keluarga coronavirus ini.Salah satu hal yang masih diteliti para peneliti adalah terkait masa inkubasi virus.Masa inkubasi adalah waktu antara seseorang terpapar hingga dirinya menunjukkan gejala awal.Biasanya, akhir masa inkubasi ditandai dengan timbulnya gejala seperti batuk dan demam. ${ }^{39}$ Menurut sejumlah penelitian, masa inkubasi atau gejala terinfeksi virus corona rata-rata muncul pada hari ke-5 setelah terinfeksi. ${ }^{40}$ Melansir CNBC, peneliti American College of Physicians mengatakan 97,5 persen orang yang terinfeksi Covid-19 akan menunjukkan gejala dalam 12 hari setelah tertular. Waktu rata-rata inkubasi adalah lima hari.

38 Merry Dame Cristy Pane, Virus Corona, https://www.alodokter.com/virus-corona , diakses pada 20 Maret 2020.

${ }^{39}$ Disampaikan oleh Lauren Ancel Meyers, seorang profesor biologi integratif dari Universias Texas, seperti diberitakan Business Insider pada tanggal 10 Maret 2020.

${ }^{40}$ Nur Rohmi Aida, Masa Inkubasi Virus Corona, https://www.kompas.com/tren/read/2020/04/03/051300965/-populer-tren-masa-inkubasi-viruscorona-lonjakan-pasien-covid-19-tanpa. 
Perkiraan akurat dari masa inkubasi penyakit untuk Covid-19 diklaim memudahkan epidemiolog untuk mengukur dinamika wabah dan memungkinkan pejabat kesehatan masyarakat untuk merancang karantina yang efektif dan langkah-langkah pengendalian lainnya.Karantina biasanya mampu memperlambat dan pada akhirnya dapat menghentikan penyebaran infeksi, bahkan untuk beberapa kasus dengan periode inkubasi yang melebihi periode karantina. ${ }^{41}$

\section{Penanggulangan Covid-19}

Vaksin untuk COVID-19 ini direncanakan baru akan tersedia paling cepat di tahun 2021, hal penting dalam penanganan pandemi penyakit coronavirus 2019 adalah menekan laju penyebaran virus atau yang dikenal dengan melandaikan kurva epidemi. Hal ini dapat menurunkan risiko tenaga medis kewalahan dalam menghadapi lonjakan jumlah pasien, memungkinkan perawatan yang lebih baik bagi penderita, dan memberikan waktu tambahan hingga obat dan vaksin dapat tersedia dan siap digunakan.

Tindakan pencegahan untuk mengurangi kemungkinan infeksi antara lain tetap berada di rumah ${ }^{42}$, menghindari bepergian dan beraktivitas di tempat umum, sering mencuci tangan dengan sabun dan air selama minimum 20 detik, tidak menyentuh mata, hidung, atau mulut dengan tangan yang tidak dicuci, serta mempraktikkan higiene pernapasan yang baik. Strategi pembatasan fisik atau social distancing diperlukan untuk mengurangi kontak antara orang yang terinfeksi dengan kerumunan besar seperti dengan menutup sekolah dan kantor, membatasi perjalanan, dan membatalkan pertemuan massa dalam jumlah besar. Perilaku pembatasan fisik juga meliputi menjaga jarak dengan orang lain sejauh 6 kaki (sekitar 1,8 meter). Bahkan, mulai tanggal 10-23 April 2020 di Provinsi Daerah Khusus Ibu Kota Jakarta - zona merah - diberlakukan PSBB (Pembatasan Sosial Berskala Besar) dalam penanganan corona virus disease 2019

\footnotetext{
${ }^{41}$ Anonim, Ahli AS: Masa Inkubasi Virus Corona Covid-19 Selama 5 Hari, https://www.cnnindonesia.com/teknologi/20200319125940-199-484943/ahli-as-masa-inkubasivirus-corona-covid-19-selama-5-hari, diakses pada 3 April 2020.

${ }^{42}$ Melakukan isolasi mandiri di rumah atau bersedia di karantina kurang lebih 14 hari lamanya bagi Pasien Dalam Pengawasan (PDP) dan bagi pasien yang telah dinyatakan positif corona.
} 
(COVID-19) yang bertujuan untuk memutus mata rantai COVID-19, dimana Jakarta merupakan epicenter dari masalah virus ini.

\section{Dampak Finansial Pandemi Covid-19}

Virus Corona tidak melanda di negara luar saja, Indonesia pun menjadi salah satu negara yang mengalami wabah pandemi corona ini.Pada hari Senin, 2 Maret 2020, Presiden Joko Widodo resmi mengumumkan adanya dua kasus virus corona di Indonesia.Dalam pengumuman itu, disebutkan dua WNI tersebut sempat kontak dengan WN Jepang yang datang ke Indonesia.Adapun WN Jepang itu terdeteksi virus corona setelah meninggalkan Indonesia dan tiba di Malaysia.Adanya kasus corona tersebut, membuat Indonesia masuk dalam peta persebaran virus corona jenis baru atau Covid-19, Coronavirus COVID-19 Global Cases by John Hopkins CSSE. ${ }^{43}$

Selain pasien COVID-19, ada beberapa pihak yang terdampak virus COVID-19 ini, yaitu:

a. Tim Medis serta Fasilitas Kesehatan Covid-19

Sosiolog Universitas Indonesia Imam Prasodjo mengajak masyarakat Indonesia untuk menggalang bantuan untuk mendukung kebutuhan tenaga medis dalam melakukan penanganan terhadap pasien COVID-19. Beliau menuturkan tidak hanya tugas pemerintah untuk memberikan Alat Pelindung Diri (APD)secukupnya kepada para dokter, perawat bahkan para petugas kebersihan, satpam dan sopir yang bekerja di rumah sakit-rumah sakit.Namun, perlu juga intervensi dari masyarakat Indonesia untuk memberikan bantuan yang menunjang penanganan medis bagi pasien COVID-19. Bantuan tersebut dapat berupa penyaluran APD, peralatan medis dan dukungan lain yang dapat memperlancar penanganan kesehatan di rumah sakit.Dengan bantuan itu, para

\footnotetext{
${ }^{43}$ Retia Kartika Dewi, "Positif Terinfeksi, Indonesia Resmi Masuk Peta Sebaran Virus Corona Global", https://www.kompas.com/tren/read/2020/03/03/084500765/positif-terinfeksiindonesia-resmi-masuk-peta-sebaran-virus-corona-global. diakses pada 23 Maret 2020.
} 
petugas kesehatan diharapkan bertambah kuat dan semangat sehingga tetap mampu menangani semua pasien COVID-19. ${ }^{44}$

APD ini menjadi kebutuhan utama dokter dan tenaga medis lainnya dalam menangani pasien infeksi virus corona (COVID-19).Penggunaan APD juga dilakukan sesuai petunjuk dan standar kesehatan dunia dari WHO. APD ini terdiri dari cover all jumpsuit yang serupa dengan baju astronot, penutup kepala, kacamata pelindung atau bahkan pelindung wajah, masker, sarung tangan, dan sepatu. Penggunaan APD umumnya juga digunakan hanya untuk sekali pakai saja. Maka dari itu, sangat dibutuhkan banyak APD bagi tim medis dalam menangani kasus pasien virus corona.

b. Warga Masyarakat Pasca Munculnya COVID-19

Pandemi virus corona telah menghancurkan sendi-sendi ekonomi, baik di level global maupun nasional.Siklus bisnis pada perusahaan di banyak sektor terganggu yang berdampak pada turunnya produksi, anjloknya pendapatan, hingga munculnya kerugian-kerugian akibat tidak seimbangnya pendapatan dan pengeluaran.

Pemutusan hubungan kerja (PHK) pun menjadi masalah serius akibat macetnya bisnis perusahaan. Sedikitnya 7.955 pekerja di Kabupaten Semarang, Jawa Tengah, harus menerima kenyataan di-PHK (342 pekerja) dan dirumahkan (7.613 pekerja). ${ }^{45}$

Sebagaimana diketahui, sejauh ini pemerintah pusat telah menyikapi pandemi COVID-19 yang tercatat ada 3.512 kasus, dan total ada 306 pasien meninggal akibat COVID-19 di Tanah Air, per 10 April 2020, dengan mengeluarkan beberapa kebijakan. Selain larangan untuk berkumpul, penggunaan masker, hand sanitizer, juga berupa bantuan untuk meringankan beban hidup rakyatnya.

44 Agus Wibowo, Sosiolog: Agar Masyarakat Galang Bantuan Dukung Tenaga Medis, https://www.covid19.go.id/2020/03/30/sosiolog-agar-masyarakat-galang-bantuan-dukung-tenagamedis/, diakses pada 30 Maret 2020.

${ }^{45}$ Elba Damhuri, Dampak Virus Corona: Berpacu Mencegah PHK Massal, https://republika.co.id/berita/nasional/news-analysis/q8kh09440/dampak-virus-corona-berpacumencegah-phk-massal, diakses 13 April 2020. 
Kebijakan itu antara lain menggratiskan tagihan PLN bagi berdaya 450 VA dan potongan 50\% untuk 900 VA (subsidi) selama 3 bulan (dari mulai bulan April, Mei dan Juni), bantuan bagi warga prakerja yang dirumahkan atau di-PHK untuk mendaftarkan diri dengan santunan Rp3.550.000 yang dikemas dalam bentuk pelatihan formal secara online.

Namun demikian, pandemi global virus corona ini membuat segala kerusakan terutama di sektor ekonomi menjadi predictable, bahkan langsung dirasakan oleh semua orang dari semua kalangan. Hampir semua negara termasuk Indonesia menghentikan sebagian aktifitas perekonomian, sehingga masih banyak pihak-pihak lainnya yang terdampak dari virus ini, diantaranya semua pelaku usaha, pekerja, petani, pedagang dan profesi lainnya serta masih banyak pula kebutuhan-kebutuhan warga untuk kelangsungan hidupnya.

\section{Pendayagunaan Dana Zakat untuk Penanggulangan Pandemi Covid-19.}

Sebagaimana kita ketahui, penggunaan zakat telah ditetapkan secara qathi untuk delapan golongan atau ashnaf. Golongan penerima zakat ini perlu diperinci lebih lanjut agar implementasinya dalam penanggulangan pandemi Covid-19 lebih operasional dan mudah dilaksanakan. Secara fikih, dana zakat dapat didayagunakan untuk :

a. Tim medis serta fasilitas kesehatan Covid-19

1. Digunakan untuk membangun fasilitas rumah sakit yang digunakan untuk perawatan pasien yang masuk kategori fakir atau miskin, misalnya untuk membangun ruang pasien kelas III, bukan ruang VIP atau ruang yang biasa digunakan untuk perawatan pasien kaya.

2. Untuk biaya pengobatan pasien corona. Agar tidak keluar dari ketentuan aşnâf zakat, maka perlu diberi batasan-batasan yang tegas, di antaranya :

a) Hanya untuk biaya pengobatan pasien yang masuk kategori penerima zakat;

b) Dana zakat tidak digunakan untuk membiayai pengobatan pasien kaya atau pasien yang biaya pengobatannya sudah dijamin oleh negara, baik melalui BPJS maupun kebijakan lain. 
c) Layanan kesehatan yang biayanya ditanggung dengan dana zakat haruslah layanan kesehatan dasar, bukan layanan kecantikan atau layanan yang bersifat tidak mendesak.

Kategori ini bisa masuk kategori mustahiq zakat manapun, baik fakir, miskin atau yang lainnya.

3. Pengadaan alat dan bahan kesehatan seperti APD untuk tim medis, handsanitizer, masker dan disinfektan dan peralatan lain yang dibutuhkan dalam pencegahan dan penanggulangan pandemi. Bagian ini bisa masuk kategori mustahiq zakat manapun, karena kebutuhan akan alat dan bahan ini bersifat umum.

b. Warga Masyarakat Pasca Munculnya COVID-19

1. Bantuan tunai untuk warga yang terkena PHK atau usahanya terdampak Covid-19 karena adanya karantina wilayah yang membat aktivitas usahanya terganggu, sehingga kesulitan untuk memenuhi kebutuhan sehari-hari keluarganya, baik dia berstatus kepala keluarga, atau anggota keluarga yang kepala keluarganya belum bisa memenuhi seluruh kebutuhan hidupnya. Pemberian pada klaster ini dapat dimasukkan sebagai fakir menurut definisi Syafi'iyyah, yakni orang yang tidak memiliki pekerjaan dan harta yang cukup untuk memenuhi kebutuhan dasarnya. Jika menggunakan standar fakir menurut Syafi'iyyah dan Hanabilah terlalu ketat sehingga masyarakat sulit memenuhi standar yang digariskan, maka bisa menggunakan kriteria fakir menurut Hanafiyyah, di mana mereka mendefinisikan fakir sebagai 'orang yang harta produktifnya tidak mencapai nişâb, atau meminjam kriteria dai Malikiyyah yang mendefinisikan fakir sebagai orang yang hartanya tidak mencukupi kebutuhan dasar selama setahun;

2. Bantuan untuk keluarga yang salah satu anggota keluarga pencari nafkah utamanya menjadi pasien Covid-19, baik berstatus PDP maupun sudah positif corona, dan ia tidak memiliki gaji tetap yang menopang kebutuhan dasar keluarganya. Golongan ini bisa masuk kategori fakir atau miskin, 
karena kepala keluarga sebagai pencari nafkah utama terhalang untuk bekerja.

3. Membayar hutang pasien yang berstatus sebagai pencari nafkah utama selama dia diisolasi, dirawat sampai sembuh dan dapat bekerja lagi seperti sediakala. Syaratnya hutang yang dibayarkan adalah hutang konsumtif, atau hutang untuk mendamaikan perselisihan sebagaimana uraian di belakang;

4. Pemberian bantuan untuk perantau yang tidak bisa pulang karena larangan mudik atau pulang kampung dan tidak memiliki harta atau bekal yang cukup untuk memenuhi kebutuhan dasarnya selama masa pandemi. Bagian ini masuk kategori Ibnu Sabil.

5. Biaya pemulangan tenaga kerja di luar negeri yang berhenti bekerja sebagai dampak dari Covid-19 di negara tempat ia mukim. Bagian ini juga masuk kategori Ibnu Sabil.

6. Penyelenggaraan pendidikan keagamaan yang teknis dan implementasinya disesuaikan dengan kebutuhan, misalnya untuk pembuatan media pembelajaran, pemenuhan alat dan perangkat belajar mengajar seperti pemasangan wifi, gaji ustadz/guru, subsidi iuran wajib siswa/santri. Bagian ini masuk kategori fi sabilillah. Jika mengikuti pendapat Yusuf alQaradawi, maka pendidikan yang dianggarkan dari zakat hanya pendidikan yang berorientasi pada i'lai kalimatillah, yakni pendidikan agama, sebagai bentuk baru jihad. ${ }^{46}$ Namun jika mengikuti pendapat kelompok muwassi'in, maka semua bidang pendidikan bisa dianggarkan dari zakat.

Dari perspektif filsafat hukum Islam, pentasarufan zakat untuk penanggulangan pandemi Covid-19 selaras dengan tujuan utama penyariatan zakat, yakni saddu khillah al-muslimin atau pemenuhan kebutuhan dasar kaum muslim, juga selaras dengan tujuan zakat dari berbagai dimensi, seperti dimensi

\footnotetext{
${ }^{46}$ Sebagai perbandingan, lihat : Wahida Z, "Sistem Pengelolaan Dana Zakat di Baitul Mal Aceh Singkil Menurut Pandangan Hukum Islam" dalam al-Muamalat Jurnal Hukum Ekonomi Syariah IAIN Langsa, Vol, III, No 1 Tahun 2017, h. 179-189
} 
tarbawiyyah (tujuan dalam aspek pendidikan), ijtima'iyyah, (tujuan zakat sebagai salah satu jaminan sosial dalam Islam), iqtisadiyyah (tujuan zakat sebagi penopang ekonomi) dan $d a$ 'wah (tujuan zakat sebagai instrumen dakwah Islam)

\section{Penutup}

Zakat merupakan pengejawantahan dari konsep "Takâful Ijtimâ'i", selaras dengan konsep "social insurance" dalam sistem ekonomi modern. Takaful Ijtima'i atau social insurance adalah sebuah konsep yang mengidealkan kondisi di mana seseorang yang mengalami kesulitan tidak merasakan sendiri kesulitannya. Dalam konsep ini, 'kehadiran negara' saja tidak cukup untuk mengatasi berbagai persoalan yang dihadapi warga terutama yang berkaitan dengan pandemi Covid19 ini. Perlu adanya gotong royong untuk meringankan beban sesama warga, sehingga kesulitan-kesulitan yang dihadapi, khususnya berkaitan dengan masalah finansial-ekonomi dapat diatasi. Zakat merupakan instrumen yang ditawarkan Islam untuk merealisasikan konsep sosial insurance dalam kadar paling minimal, namun sangat dapat membantu meminimalisir beban atau kesulitan yang dirasakan di tengah pandemi ini.

\section{DAFTAR PUSTAKA}

Abdullah, Ainiah, "Maslahah dalam Pelegalan Tas'ir Ibnu Qayyim al-Jauziyyah", dalam al-Muamalat Jurnal Hukum Ekonomi Syariah IAIN Langsa, Vol IV, No 01. Tahun 2019

Aida, Nur Rohmi, Masa Inkubasi Virus Corona, https://www.kompas.com/tren/read/2020/04/03/051300965/-populertren-masa-inkubasi-virus-corona-lonjakan-pasien-covid-19-tanpa.

Anonim, Ahli AS: Masa Inkubasi Virus Corona Covid-19 Selama 5 Hari, https://www.cnnindonesia.com/teknologi/20200319125940-199484943/ahli-as-masa-inkubasi-virus-corona-covid-19-selama-5-hari diakses pada 3 April 2020. 
Beik, Irfan Syauqi, d "Fiqh of Asnaf in The Distribution of Zakat : Case Study in The National Board of Zakat of Indonesia (Baznas)", al-Infaq: Jurnal Ekonomi Islam, Vol. 6, No 2, September 2015

bin Yusof, Fakhruddin Arrazi, "Status Hukum Pemberian Zakat bagi Ibnu Sabil yang Kaya di Tempat Asal (studi komparatif antara Imam Kamal Al-Din Muhammad 861 M dan Imam Nawawi 1277 M)”, Skripsi pada Jurusan Perbandingan Madzhab dan Hukum UIN Suska Riau, 2019

Damhuri, Elba, Dampak Virus Corona: Berpacu Mencegah PHK Massal, https://republika.co.id/berita/nasional/news-analysis/q8kh09440/dampakvirus-corona-berpacu-mencegah-phk-massal, diakses 13 April 2020.

Dewi, Retia Kartika, "Positif Terinfeksi, Indonesia Resmi Masuk Peta Sebaran Virus

Corona

Global", https://www.kompas.com/tren/read/2020/03/03/084500765/posi tif-terinfeksi-indonesia-resmi-masuk-peta-sebaran-virus-corona-global. diakses pada 23 Maret 2020.

Dzulfaroh, Ahmad Naufal, "Update Virus Corona di Indonesia: Rincian Kasus Covid-19 di

Provinsi", https://www.kompas.com/tren/read/2020/04/02/054700165/up date-virus-corona-di-indonesia--rincian-kasus-covid-19-di-32-provinsi. Diakses pada 1 April 2020.

Fariza, Siti, dkk.,"Aplikasi Kaedah Fiqh Al-Darurah Tuqaddar Biqadariha dalam Agihan Zakat untuk Mangsa Banjir" dalam Jurnal Infad, Vol. 8 Tahun 2018

Firdaus, Muhammad, "Investasi Uang Zakat oleh Lembaga Zakat Menurut Pandangan Islam", dalam JII, Vol. 1 No, 2016

Heymann, David L; Shindo, Nahoko (2020). "COVID-19: what is next for public health?". The Lancet. Elsevier BV. 395 (10224): 542-545.Lihat: Wikipedia, Penyakit Koronavirus, https://id.wikipedia.org/wiki/Penyakit_koronavirus_2019, diakses pada 1 April 2020.

https://covid19.who.int/. Diakses pada 29 April 2020 pukul 07.26. 
https://kawalcovid19.blob.core.windows.net/viz/statistik_harian.html, Diakses pada 29 April 2020 pukul 07.26.

https://www.who.int/publications/en/

Ibn al-Qayyim Muhammad bin Abin Bakr, I'lam al-Muwaqi'in 'an Rabb al'Alamin (Beirut : Dar al-Kutub al-Ilmiyyah, $1411 \mathrm{H}$ )

Isbaniah, Fathiyah, dkk.,Pedoman Kesiapsiagaan Menghadapi Coronavirus Disease (COVID-19), Kementerian Kesehatan RI Direktorat Jenderal Pencegahan dan Pengendalian Penyakit: Jakarta Selatan, 2020, hlm. 11.

JAbdul Aziz, amal, "Dekonstruksi Paradigmatik PengembanganZakat: Analisis

Kritis PemikiranYusuf al-Qaradawi", dalam Ijtihad: Jurnal Wacana Hukum Islam dan Kemanusiaan, Vol. 12 No. 2 (2017)

Muhammad Ammar Harith Adris dan Mohd Anuar Ramli , "Golongan Gelandangan di Malaysia: antara Perluasan Tafsiran Asnaf Ibnu AlSabil dan Al-Riqab", dalam Najahudin Lateh, Isu-Isu Kontemporer dalam Zakat, Wakaf dan Filantropi Islam (Selangor Darul Ihsan: Akademi Pengajian Islam Kontemporari, 2017)

Nasar, M Fuad, 2018, Capita Selecta Zakat : Esei-Esei Zakat, Aksi Kolektif Melawan Kemiskinan (Yogyakarta: Gre Publishing

Pane, Merry Dame Cristy, Virus Corona, https://www.alodokter.com/virus-corona , diakses pada 20 Maret 2020.

Rosli, Mohd Rilizam, dkk., “Asnaf Zakat Distribution Mechanism in Today's World”, dalam International Journal of Academic Research in Business \& Social Science, Vol. 8 No 4, April 2018

Sarwat, Ahmad, SeriFiqih Kehidupan : Zakat (Jakarta : DU Publishing, 2011)

Suryadi, Andi, "Mustahiq dan Harta yang Wajib Dizakati Menurut Kajian Para Ulama", dalam Jurnal Tazkiya, Vol. 9, No 1 (Januari-Juni) 2019

Syamghuli, Rasyid al,“Maqasid al-Syariah Li Nidzam al-Zakah”, dalam Jurnal Majallah Jamiah al-Quds al-Maftuhah li al-Buhuts al-Insaniyyah wa alIjtima'iyyah, Vol. 46, 2018

Thabari, Muhammad bin Jarir al, Jami' al-Bayan (Tanpa Kota: Muassasah arRisalah, $1420 \mathrm{H})$ 
Al-Muamalat: Jurnal Hukum \& Ekonomi Syariah

Vol. 5 No. 1 Edisi. 1 hal. 1-26

P-ISSN 2460-5115|E-ISSN 2656-288X

DOI 10.32505/muamalat.v5i1.1849

Triana, Yeni, dkk, Kontekstualisasi Pendayagunaan Zakat di Badan Amil Zakat Nasional (Baznas) Kota Pekanbaru Berdasarkan Undang-Undang Nomor 23 Tahun 2011 Tentang Pengelolaan Zakat, dalam Jurnal Hukum Novelty Vol. 9 No. 1 Agustus 2018

Wahida Z, "Sistem Pengelolaan Dana Zakat di Baitul Mal Aceh Singkil Menurut Pandangan Hukum Islam" dalam al-Muamalat Jurnal Hukum Ekonomi Syariah IAIN Langsa, Vol, III, No 1 Tahun 2017

Waluya, Atep Hendang, “Analisis Makna fi Sabilillah dalam Q.S. Taubah (9): 60 dan Implementasinya dalam Perekonomian”, dalam Jurnal Rausyan Fikr, Vol. 13 No. 12017

Wibowo, Agus Sosiolog: Agar Masyarakat Galang Bantuan Dukung Tenaga Medis, $\quad$ https://www.covid19.go.id/2020/03/30/sosiolog-agarmasyarakat-galang-bantuan-dukung-tenaga-medis/, diakses pada 30 Maret 2020.

Zuhaili, Wahbah al, al-Fiqh al-Islami wa Adillatuh, (Damaskus: Dar el-Fikr, 1985)

Zulhamdi, "Urgensi Lembaga Amil Zakat dan Perkembangannya di Aceh", dalam Al-Muamalat Jurnal Hukum Ekonomi Syariah IAIN Langsa, Vol. II, No 1 Tahun 2016 